\title{
o performativo em diário da catástrofe brasileira: UMA ANÁLISE DA ASSINATURA DE RICARDO LÍSIAS
}

The performative in Diário da catástrofe brasileira: an analysis of Ricardo Lisias' signature

\section{Nivana Ferreira da Silva ${ }^{1}$}

Resumo: Na série de ebooks Diário da catástrofe brasileira (2019, 2020), de Ricardo Lísias, são notáveis a expressiva referência à forma do material, o aproveitamento das tecnologias e o trânsito entre vida e obra, características que já estavam presentes em textos anteriores do autor, ainda que de outra maneira. Sendo assim, proponho uma discussão sobre o performativo (AUSTIN, 1998; DERRIDA, 1991; FISH, 1982) nos ebooks e na relação que estabelecem com publicações precedentes de Lísias, partindo da hipótese de que, performativamente, o autor lança mão de certas estratégias a favor da circulação de sua assinatura no campo literário e, sobretudo, considerando o contexto da literatura contemporânea, que, conforme defendo, faz emergir novas questões para pensarmos o performativo e seus desdobramentos.

Palavras-chave: Literatura contemporânea; Performativo; Iterabilidade; Assinatura; Ricardo Lísias.

Abstract: On the ebooks series Diário da catástrofe brasileira (2019, 2020), by Ricardo Lisias, the expressive reference to its form, the usage of technologies and the transit between life and work are noticeable, traces already present in previous texts of the author, even though in a different way. Thus, I propose a discussion about the performative (AUSTIN, 1998; DERRIDA, 1991; FISH, 1982) in ebooks and in the relation they establish with former Lísias'publications, assuming he performatively makes use of certain strategies that support the circulation of his signature on the literary field and, furthermore, considering the contemporary literature context which, as I defend, brings out new questions for us to think the performative and its outcomes.

Keywords: Contemporary Literature; Performative; Iterability; Signature; Ricardo Lísias.

1 Professora do Instituto Federal de Educação, Ciência e Tecnologia da Bahia, campus Valença BA. Doutoranda do Programa de Pós-Graduação em Literatura e Cultura, da Universidade Federal da Bahia, e integrante do grupo de pesquisa "Leituras Contemporâneas - Narrativas do século XXI", coordenado pela professora Dr.a Luciene Azevedo.E-mail: nivana.fs2@gmail.com 


\section{consideracões iniciais}

Colocar-se diante do presente para investigá-lo implica, quase sempre, o desafio de renunciar a um distanciamento reflexivo e enfrentar um contato direto com o objeto de estudo. As ferramentas de análise desse objeto, quando não surgem junto com ele, demandam releituras ou revisões das bibliografias já conhecidas, 0 que traz o risco da incerteza e das perguntas para as quais nem sempre temos respostas. Contemporaneamente, a literatura tem experimentado um encontro com novas formas e outros campos artísticos, ensaiando uma "inespecificidade" para usar a expressão da crítica argentina Florencia Garramuño (2014, n.p.) - que, por vezes, estreita o diálogo entre o literário e as artes plásticas, ou entre ficção e realidade.

Nesse cenário, o nome do paulistano Ricardo Lísias merece atenção. Uma de suas marcas autorais diz respeito ao modo como articula vida e obra, conferindo um caráter inespecífico a muitos de seus textos, como no caso da série de ebooks intitulada Diário da catástrofe brasileira $(2018,2019)^{2}$. Considerando que há um procedimento performativo nos ebooks e na sua relação com outros textos do autor, interessa-me discutir como, com o Diário, Lísias arrisca-se em certas estratégias autorais para manter seu nome circulando no campo literário ou, em outras palavras, para promover sua assinatura.

\section{o performativo e a literatura contemporânea}

Os ebooks têm sido publicados através do Kindle Direct Publishing (KDP), plataforma de autopublicação da Amazon. Não se trata, então, de um texto finalizado, mas de um trabalho em andamento que, conforme apresentado pelo autor, "se estenderá até o final de $2022^{1 / 3}$. O prazo estabelecido não é fortuito e coincide com o término do mandato do presidente do Brasil eleito em 28 de outubro de 2018 , isso porque o texto traz as entradas de um diário escrito por Lísias a partir

2 Até o envio deste artigo, foram publicados Diário da catástrofe I - transição, Diário da catástrofe II - a pulsão de morte no poder, Diário da catástrofe III - o nazifascismo se consolida, Diário da catástrofe IV - o corpo de Lula e Diário da catástrofe V-Cultura e política (1969-2019) alguns esboços, sendo que os dois primeiros volumes apresentam até o momento, respectivamente, seis e três atualizações. Na discussão apresentada, não cito o quinto volume da série.

3 A citação refere-se a um post de Lísias em sua conta no Facebook em 16 de dezembro de 2018, quando, por ocasião da publicação do primeiro volume de Diário da catástrofe brasileira, o autor divulgou em suas redes sociais o objetivo do projeto. Disponivel em: $<$ https://bit.ly/zatpHT7 $>$. Acesso em 20 dez. 2018. 
dessa data, sendo um de seus objetivos "entender o desdém à campanha que acabou vencedora na catástrofe eleitoral de outubro"4.

O autor também projetou que cada novo volume fosse publicado trimestralmente e atualizado todo mês. No entanto, o texto anterior à atualização seria apagado, ficando o leitor de posse somente das versões atualizadas, isto é, para estar up to date com o material, deve-se fazer o download das atualizações gratuitamente, ou, nas palavras de Lísias: "[...] todas as atualizações que eu colocar nesse volume I podem ser baixadas de graça por quem já tiver o ebook. A questão é que se atualizar, perde o que tem antes: e é essa a minha vontade" ${ }^{\prime \prime}$.

A materialização dessa vontade faz cintilar no Diário uma expressiva referência à forma do material, ao aproveitamento das tecnologias e ao trânsito do autor entre vida e obra, questões das quais falarei adiante e que, sobretudo a última, já estavam presentes em publicações precedentes, ainda que de outra maneira. Nesse sentido, acredito que os ebooks apresentam um procedimento performativo que também se desdobra na relação que estabelecem com textos anteriores do autor. Mais do que isso, é possível arriscar a hipótese de que, performativamente, Lísias utiliza estratégias autorais em prol de sua assinatura.

Mas antes de desenvolver a hipótese, é preciso fazer uma breve digressão teórica quanto à origem, por assim dizer, do performativo, que nasce na filosofia e tem desdobramentos significativos dentro da própria filosofia, dos estudos linguísticos, da teoria da comunicação e da teoria literária, por exemplo. A partir desse tratamento inicial do performativo, problematizarei algumas de suas consequências teóricas que julgo rentáveis para pensar as questões que atravessam a discussão proposta.

Danilo Marcondes (1998), tradutor para o português da famosa obra de John Langshaw Austin, How to do things with words ${ }^{6}$, afirma que, em um primeiro momento, o filósofo britânico introduz na filosofia a noção de performativo em oposição à de constativo e, posteriormente, apresenta a noção sob uma visão mais ampliada que caracteriza o uso da linguagem como um todo, o que é chamado de ato de fala. Inicialmente, na conferência "Performativo-constativo", Austin (1998)

4 Cf. post do autor em sua conta no Facebook em 18 de dezembro de 2018. Disponível em <https:/l bit.ly/2TELTUl>. Acesso em 22 dez. 2018.

5 Conforme postagem em seu perfil no Facebook em 22 de dezembro de 2018. Disponível em: $<$ https://bit.ly/38rgZWQ >. Acesso em 23 dez. 2018.

6 AUSTIN, J. L. Quando dizer éfazer: palavras e ação. Tradução de Danilo Marcondes de Souza Filho. Porto Alegre: Artes Médicas, 1990. 
levou em conta que os constativos apenas gerariam enunciados declarativos sobre as coisas, diferentemente dos performativos, que, para além da constatação, produziriam um efeito no mundo, operando um fazer:

O enunciado constativo tem, sob o nome de afirmação tão querido dos filósofos, a propriedade de ser verdadeiro ou falso. Ao contrário, o enunciado performativo não pode jamais ser nem um nem outro: tem sua própria função, serve para realizar uma ação. 'Formular um tal enunciado' é realizar a ação, a ação, talvez, que não poderia ser realizada, ao menos com uma tal precisão, de nenhum outro modo. Eis alguns exemplos: Batizo este navio 'Liberdade'. Peço desculpa. Eu te desejo boas-vindas. Eu te aconselho a fazer (AUSTIN, 1998, p. 111, grifo do autor).

Os exemplos vão além daquilo que enunciam e se materializam em ações, ou seja, realizam algo ao serem proferidos. Nesse caso, ao contrário do constativo, que pode ser verdadeiro ou falso, o performativo, se emitido em condições inapropriadas, poderá ser "infeliz (unhappy)" (AUSTIN, 1998, p. 112), quer dizer, o ato pretendido não se realizará com a formulação de seu enunciado. O professor de Oxford ilustra a questão destacando que, se alguém diz o performativo "eu prometo..." sem a intenção de cumprir tal promessa por meio de uma ação, ou se pretende batizar um navio sem ser a pessoa autorizada para tal, teríamos, respectivamente, uma promessa vazia e um batismo sem validade, uma "infelicidade", portanto.

Na mesma conferência, no entanto, a oposição entre performativo e constativo dá lugar ao argumento de que há um deslocamento da referência associada, previamente, a cada um deles (dizer sobre o mundo ou praticar uma ação no mundo) para o contexto: regras convencionais condicionariam que determinados enunciados em determinadas situações fossem ou não performativos. "Daí Austin concluir que uma afirmação pode ser um performativo. Pode-se dizer que por detrás de cada afirmação há uma forma não explícita de um performativo, um performativo mascarado" (OTTONI, 1998, p. 37). Logo, o chamado constativo, proferido em certos contextos, passa a também ser um enunciado que gera ou modifica uma ação, produzindo um efeito ou transformando uma situação.

Uma das consequências derivadas da leitura de Austin sobre o performativo está na obra de Jacques Derrida (1991), em seu famoso texto "Assinatura acontecimento contexto", no qual a abordagem austiniana é capitalizada para a 
noção derridiana de iterabilidade, relacionada à propriedade do signo de se repetir de maneira diferente:

É preciso que [minha 'comunicação escrita'] seja repetível - iterável - na ausência absoluta do destinatário [...]. Essa iterabilidade (iter, derechef, viria de itara, outro em sânscrito, e tudo o que segue pode ser lido como a exploração da lógica que liga a repetição à alteridade) estrutura a marca da própria escrita [...] (DERRIDA, 1991, p. 19).

Adianto que essa noção pode ir ao encontro da nossa hipótese se consideramos o contexto da literatura contemporânea, conforme discutirei. Mas antes, como se coloca Derrida diante da obra de Austin?

Para a visão derridiana, embora sejam reconhecidas as dificuldades com as quais Austin teve que lidar para a construção de sua análise, há um problema nas formulações do britânico quando, em How to do things with words, a oposição entre verdade-falsidade (atribuída ao constativo) dá lugar ao performativo enquanto uma "comunicação" que transporta conteúdo semântico, "já construído e vigiado por um objeto de verdade [...] comunicação de um sentido intencional" (OTTONI, 1998, p. 53). Em outras palavras, a despeito da posterior conclusão austiniana de que por detrás das afirmações - a princípio julgadas como verdadeiras ou falsas - existe um performativo não explícito (levando, assim, a noção de performativo para pensar a linguagem como um todo), haveria a comunicação de um conteúdo já construído, determinado e, portanto, puro, o que é problemático para Derrida. Ademais, de acordo com Austin, os atos de fala demandariam um valor de contexto determinável, em que a intenção dos sujeitos falantes seria presente e consciente na totalidade do enunciado. Se o questionamento da metafísica da presença é o centro gravitacional da desconstrução, a apropriação austiniana do performativo é, além de rasurada, redefinida:

Operformativo é uma 'comunicação' que nãose limita essencialmente a transportar um conteúdo semântico já constituído e vigiado por um aspecto da verdade [...] as análises de Austin requerem permanentemente um valor de contexto e até de contexto exaustivamente determinável [...] e a longa lista dos fracassos (infelicities) de tipo variável que podem afetar o acontecimento do performativo retorna sempre a um elemento daquilo que Austin chama de contexto total. Um desses 
elementos essenciais - e não um entre outros - permanece sendo classicamente a consciência, a presença consciente da intenção do sujeito falante à totalidade de seu ato locutório (DERRIDA, 1991, p. 27-28).

Alvo também de crítica é a atribuição anormal, ou parasitária/parasítica, à possibilidade de um enunciado ser citado em outras situações contextuais, como pontuado por Austin, consequência não somente do valor determinável atribuído ao contexto, mas, principalmente, do direcionamento da teoria dos atos de fala para a linguagem ordinária, que exclui a escrita, passível de ser citada, o que quer dizer que, se o contexto está previsto de antemão, então os enunciados não podem ser repetidos. Para Derrida, essa suposta anormalidade, como considera Austin, é nada mais do que a própria condição sine qua non da linguagem, isto é,

[ele] postula que esse uso da língua, chamado por Austin de 'parasítico' em oposição ao uso ordinário, não nomeia um abismo em torno da linguagem ordinária, mas, 'em vez disso, um risco interno e uma condição de possibilidade' (p. 205), exatamente porque ambos os usos seguem um princípio maior de funcionamento da linguagem, a iterabilidade. Qualquer enunciado performativo repete convenções prévias. Ele funciona na iteração dessas convenções diante da instância do Outro, deslocando o enunciado da 'intenção' e do contexto prévios e assim provocando, necessariamente, rupturas (SILVA; VERAS, 2016, p. VIII, grifo meu).

Diante do exposto, o que me importa pensar agora para o desenvolvimento da hipótese apresentada, antes da reflexão teórica, dialoga com o seguinte incômodo de leitura: se o performativo está na linguagem como um todo, seguindo "um princípio maior, a iterabilidade", incluindo, assim, a linguagem literária, o que marca a diferença no procedimento performativo usado por Ricardo Lísias e como se daria sua "intenção deslocada"? Trago essa questão sem perder de vista outra central: como o performativo [e uma suposta "intenção deslocada"] contribui para a construção da assinatura de Lísias? Creio que não só o trabalho do autor, mas os procedimentos para a inscrição de um nome na literatura contemporânea, que trazem novas problematizações para o performativo, ensejam algumas respostas. 
Como disse anteriormente, em Diário da catástrofe brasileira, Lísias se vale da tecnologia, de uma expressiva alusão à forma do material e da mobilização das fronteiras entre vida e obra. O Diário não se restringe a esses três aspectos - que, por sinal, não configuram, exatamente, uma novidade no trabalho do autor - mas é justamente por isso que os considero pertinentes para discutir o performativo nos ebooks e na relação que estabelecem com os textos anteriores, porque, se por um lado, o autor dá continuidade a uma espécie de "linha de produção" - especialmente pela articulação entre vida e obra por outro, interrompe essa cadeia e agrega algo diferente ao seu trabalho. Em outras palavras, é possível afirmar, preliminarmente, que há um deslocamento $\mathrm{e}$, ao mesmo tempo, uma repetição em outro contexto que caracterizam a iterabilidade do performativo.

A diferença toma lugar com a própria denominação dada pelo autor ao Diário, um "experimento", cujas primeiras linhas foram escritas em 28 de outubro de 2018, pois, nesse dia,

há algumas horas, foi eleito presidente da república o candidato mais nefasto da história eleitoral brasileira. [...]. Tentarei entender como chegamos até aqui. [...]. Agora, à meia noite, não tenho nenhum método. Comecei esse texto de repente, ao ver um caderno vazio na mesa antes de dormir. Ele está me trazendo algum tipo de bem estar. Não pretendo abandoná-lo. Para ter essa certeza, preciso de ainda mais planejamento (LÍSIAS, 2018a, n.p.).

A dita "falta de método" está ligada ao caráter experimental que o autor atribui ao trabalho, embora saibamos que a opção por uma plataforma de autopublicação virtual e o recurso da atualização dos ebooks indique planejamento prévio, o que caracteriza uma estratégia autoral de Lísias e nos faz questionar, por exemplo, o porquê dessas escolhas7. Assim, acredito

7 Lísias parece optar pela plataforma digital para alcançar mais facilmente os leitores, que podem fazer o download dos ebooks por um preço acessível (pouco menos de quinze reais) e atualizá-los gratuitamente. Além disso, o autor tem um controle ainda maior da produção e circulação do texto, porque esse, sendo publicado pelo KDP, não está vinculado a nenhuma editora. Assim, Lísias vai fomentando a circulação de seu nome de autor, aproveitando-se da pertinência do conteúdo sobre 
que falar em "experimento" diz mais respeito à dificuldade de definição do que vem a ser o Diário da catástrofe brasileira, afinal, estamos diante de um texto não literário, mas que parece vir a lume como uma maneira calculada de o autor manter a circulação de seu nome no campo literário? Um "experimento" para testar a assinatura? Voltarei novamente a essas questões e seus desdobramentos.

Visando "entender como chegamos até aqui", o primeiro volume foi publicado como uma espécie de "libelo contra os intelectuais de esquerda"s, uma vez que o autor faz uma crítica contundente a alguns nomes da intelectualidade brasileira que, segundo ele, falharam em seus diagnósticos pré-eleitorais ao afirmarem que o então presidente da república jamais seria eleito. Após o resultado, esses mesmos críticos, conforme aponta, se esforçaram para explicar o sucesso da direita nas urnas, apesar de não reconhecerem as próprias incorreções e a ineficiência das antigas bibliografias:

Desde antes da eleição, sinto uma sensação de 'falência epistemológica'. Uso essa expressão na falta de outra. Ninguém consegue nos explicar muita coisa. Achei que depois do resultado, algo novo pudesse aparecer no campo da análise política. De forma nenhuma. Nossos intelectuais de sempre continuaram sendo convidados pelos mesmos espaços para dar as explicações de hábito. [...]. As antigas referências não explicam o que aconteceu. Os intelectuais estão aparvalhados porque suas bibliografias se tornaram inócuas. Naufragaram (LíSIAS, 2019a, n.p.).

Lísias, então, considera que os analistas de plantão tentam explicar tudo, porém não voltam atrás quando cometem erros em suas análises, ou seja, não as revisam e seguem adiante, o que, podemos dizer, é sintomático do ambiente virtual, onde as informações tomam corpo de maneira muito acelerada e, por conseguinte, a reflexão e a ponderação ficam em segundo plano. Cabe notar que a acusação do autor, no Diário, simula que vai operar sob essa lógica do esquecimento, do avançar vertiginoso da informação e da crítica - quando propõe atualizar os ebooks e apagar suas versões anteriores

o qual quer tratar e das facilidades que esse "novo" modo de produção pode oferecer.

8 Aqui, faço referência à matéria sobre os ebooks publicada na Revista Época em 15 de dezembro de 2018: "O escritor Ricardo Lísias faz libelo contra os intelectuais e suas velhas bibliografias". Disponível em: <https://glo.bo/2UikigR $>$. 
- mas, ao reescrever, com alterações, o mesmo texto dos volumes publicados, o autor tenta revisar e reiterar o que já foi dito. Em nome de quê?

Quando defendo que, no Diário, há uma articulação entre vida e obra, considero que a voz de Lísias no texto, buscando compreender a "catástrofe brasileira", está imbrincada aos seus posicionamentos nas redes sociais, aproveitando-se do suporte tecnológico e da exposição midiática. Assistimos à crítica e resistência de Lísias, que não deixam de estar relacionadas, especificamente, a um investimento no seu próprio trabalho e na reafirmação do seu nome de autor e, de forma geral, à reflexão sobre os modos de produção e circulação dos textos no contemporâneo. A persona do autor, com os posicionamentos que diz assumir - sua vida (poderíamos dizer?) - atravessando seu texto, sua obra. Performativamente, Lísias utiliza esse recurso, repete uma velha estratégia em um novo contexto, endossando "a possibilidade de todo enunciado performativo ser 'citado'" (DERRIDA, 1991, p. 30), quer dizer, repetido de outra forma. Entretanto, essa repetição, marcada pela diferença, suscita um novo olhar sobre a sua consequente "intenção deslocada", olhar esse que tem como elemento catalisador o próprio contemporâneo.

Não é de hoje que Lísias torna porosas as fronteiras entre vida e obra, realidade e ficção. O céu dos suicidas (2012), Divórcio (2013) e a série de ebooks Delegado Tobias (2014a), além de serem textos que apresentam referências factualmente rastreáveis, culminaram - cada um à sua maneira - em repercussões e desdobramentos, fomentando um empenho do autor para fazer circular seu nome e sua obra por meio de aparições públicas e do uso expressivo das mídias sociais. A disposição de Lísias em embaralhar o ficcional e o factual se dá após a publicação de O livro dos mandarins (2009) - até aqui, ainda separávamos, com certa segurança, autor e narrador, realidade e ficção - quando o autor passa a endereçar para um grupo de pessoas selecionado por ele, por correio e por e-mail, textos com proposta gráfica artesanal, já apostando no uso de seu nome próprio no interior das narrativas, fazendo minar o conhecido pacto ficcional e inaugurando o que chamei anteriormente de uma "linha de produção". Com a publicação de $O$ céu dos suicidas, temos a história contada pelo narrador-personagem Ricardo, em torno da morte de André Silva, mesmo nome do amigo do autor que cometera suicídio. No livro Divórcio, há o relato do também 
narrador-personagem Ricardo Lísias, escritor, sobre o fim de seu casamento, o que, inevitavelmente, remete ao seu divórcio ocorrido na "vida real".

Em Delegado Tobias, por sua vez, o autor estica ao máximo a tensão entre ficção e realidade, pois, além do uso da homonímia, escancara ainda mais sua presença dentro e fora do texto, usando o facebook como suporte ficcional e envolvendose com os desdobramentos da série. Em Diário da cadeia: com trechos da obra inédita impeachment - Eduardo Cunha (pseudônimo) (2017), a despeito de não encontrarmos a equivalência entre autor e narrador, é possivel dizer que o texto também funde vida e obra, já que, ao ser ficcionalmente assinado pelo ex-deputado, faz alusão à sua prisão real, ocorrida em outubro de 2016. Aqui, então, observamos a retomada explícita de um interesse genuíno do autor em temas de teor político e social, muito presente em seus primeiros livros, que se repete no ensaio publicado em seguida, Sem título: uma performance contra Sérgio Moro (2018c) ${ }^{9}$, e é reiterado, acentuadamente, em Diário da catástrofe brasileira.

Logo, o que vemos é a repetição de um modus operandi que se manifesta no limiar entre vida e obra. Cada publicação mencionada, no entanto, operacionaliza de uma forma diferente, em outros contextos - para usar o vocabulário já apresentado aqui - a disposição do autor em atuar nesse limiar. Se os livros considerados pela recepção como autoficcionais podem ser lidos na clave do que Diana Klinger (2012, p. 49) denomina de "dramatização de si", que, como pontua, "supõe, da mesma maneira que ocorre no palco teatral, um sujeito duplo, ao mesmo tempo real e fictício, pessoa (ator) e personagem. [...] a dramatização supõe a construção simultânea de ambos, autor e narrador" (KLINGER, 2012, p. 49, grifos da autora), o que seria uma suposta "dramatização de si" no Diário da catástrofe brasileira?

Acredito que há nos ebooks uma repetição e um deslocamento da "dramatização de si", porque o autor continua pulverizando sua voz, porém não mais sob o estatuto ficcional dos textos (sempre defendido por ele), transitando entre

9 Se em Sem título: uma performance contra Sérgio Moro temos a repetição do tema de cunho político e, ao mesmo tempo, a marca da diferença em relação aos textos anteriores, já que o livro foi publicado como um ensaio e não como ficção, por que a análise do performativo em Lísias toma Diário da catástrofe brasileira como ponto de partida? Acredito que a série de ebooks configura uma inflexão bastante significativa para pensar a ligação entre a noção de performativo e a assinatura porque, diferentemente de Sem título, o autor hesita quanto à definição do gênero (com exceção do quarto volume, conforme trago na seção "O não literário da literatura"), muda radicalmente o formato, o suporte e o modo de publicação, o que considero um investimento importante para a promoção da assinatura. Sendo assim, penso que Diário da cadeia e o ensaio contra Moro repetem características e encaminham algumas diferenças na obra de Lísias que se concretizam em Diário da catástrofe. 
narrador e autor, como ocorria antes. No Diário, teríamos a dramatização da voz que reflete a consciência política do cidadão Ricardo Lísias? Do autor que quer testar a tecnologia e investir em outra forma de circulação editorial? Do crítico que quer pensar, não só o caos político, mas também o contemporâneo? Os questionamentos são indicativos da saída da ficção que o "experimento" introduz e que diz respeito à grande diferença com o que havia sido produzido por Lísias até o momento, ainda que essa diferença seja atravessada por uma repetição que se dá em outro contexto, caracterizando o performativo do texto e da sua relação com as obras anteriores. Mas, retomando os questionamentos que finalizaram a primeira parte desta seção, se o performativo está na linguagem como um todo, seguindo "um princípio maior, a iterabilidade", o que marca a diferença no procedimento performativo usado por Ricardo Lísias e como se daria sua "intenção deslocada"? Como o performativo [e uma suposta "intenção deslocada"] contribui para a construção da assinatura de Lísias? Conforme sinalizei, falar aqui em "intenção deslocada", formulação que emerge da releitura derridiana de Austin, requer que levemos em conta outros aspectos importantes do âmbito da literatura contemporânea.

Gonzalo Aguilar e Mario Cámara (2017, p. 147) consideram que o autor do século XXI está imerso em um "novo ecossistema literário e cultural", que

tem exigido cada vez mais [sua] presença física, ao mesmo tempo em que sua projeção virtual [...]. O eixo presencial compõe-se de um número crescente de feiras de livros nacionais e internacionais, onde os escritores autografam exemplares ou falam sobre seu ofício [...]. O virtual consiste nos perfis que os escritores possuem no Facebook, com informações que combinam a autopromoção, a discussão e a minúcia cotidiana, e na escrita de blogs, que podem ser pessoais ou estar hospedados nos sites das editoras que publicam seus livros [...] (AGUILAR; CÁMARA, 2017, p. 147).

Assim, diante desse "novo ecossistema literário", como pensar a "intenção deslocada", resultante da iterabilidade do performativo?

Quando coloca em xeque o posicionamento de Austin referente ao contexto e à intenção dos falantes envolvidos no enunciado, Derrida considera que "a ausência do emissor, do destinatário, na marca que ele abandona, é cortada dele e continua a produzir efeitos para além de sua presença e da atualidade presente do seu querer dizer [...]" (DERRIDA, 1991, p. 16, grifo meu), isto é, o alcance do enunciado, a 
marca deixada, independeria de um referente, da presença dos interlocutores e da sua intenção, uma vez que, na visão derridiana, ela é deslocada e reapropriada em outros contextos. No entanto, chama a atenção que, na literatura contemporânea, um suposto "querer dizer" enviese a obra de alguns autores.

Há um bom número de produções atuais em que é notável o autor "em cena", tentando reverberar esse "querer dizer" e, de algum modo, "controlar" o dito, uma interferência que, no entanto, não opera como uma garantia para a intepretação ou uma inconteste chave de leitura, já que pode expor o leitor a mais riscos do que certezas. Desse modo, no caso Lísias, há uma disposição do autor para atuar confundindo o limiar entre o real e o ficcional, para aproximar-se do leitor, especializado ou não, para testar novas estratégias de produção e circulação, em suma, para tentar interferir nas apropriações sobre a obra. E é aqui onde acredito existir uma diferença na ideia de "intenção deslocada", pois, se por um lado, vemos as repetições e diferenças ao longo do trabalho do autor, na matéria-prima da qual faz uso, por outro, sua atuação marcante influencia as interpretações, levandonos a concluir que a "produção de efeitos" não ocorre somente "para além do seu querer dizer".

Austin apresenta o contexto como algo pronto para ser identificado, uma presença materializada, dependente de quem fala. Derrida, por sua vez, advoga pela ausência, supervaloriza a escrita, considera o contexto como aquilo que ainda será construído e enfraquece a intenção. Apontando as brechas nas duas formulações, Stanley Fish (1982) argumenta que nem a presença, tampouco a ausência absoluta resolvem a questão. Para o crítico literário, qualquer enunciado escrito ou falado, literário ou não literário, terá sentido "dentro de um sistema de inteligibilidade e nunca terá o status de algo determinado fora de qualquer sistema que seja" (FISH, 1982, p. 711, tradução minha) $)^{10}$. Trocando em miúdos, esse sistema que orbita os enunciados configura um conjunto de acordos, pressupostos, situações que influenciam na interpretação, sendo, inclusive, a própria presença ou ausência do emissor um desses elementos.

Fish traz na epígrafe de sua discussão a pertinente frase do produtor de cinema Samuel Goldwyn: "O mais importante na atuação é a honestidade. Uma vez que você aprende a fingi-la, você está no jogo" (FISH, 1982, p. 693, tradução minha) $)^{11}$.

10 "[...] within a system of intelligibility and will never have the status of something determined outside of any system whatsoever" (FISH, 1982, p. 711).

11 "The most important thing in acting is honesty; once you learn to fake that, you're in" (FISH, 
A presença de quem atua como honesto, ou o seu "querer atuar como honesto", ou, ainda, a consciência de que se está atuando como honesto, é importante para os modos como essa "atuação" será recebida. No contexto da literatura contemporânea, o "querer dizer" do autor faz parte de um "sistema de inteligibilidade" e é peça fundamental que contribui para o jogo interpretativo, porquanto o autor "em cena" - sendo fruto "de uma atuação, de um sujeito que 'representa um papel' na própria 'vida real', na sua exposição pública, em suas múltiplas falas de si, nas entrevistas, nas crônicas, nas palestras [...]" (KLINGER, 2012, p. 50) - influencia o modo como a obra será lida. O leitor, então, é impactado por essas atuações, que podem não funcionar como farol que ilumina a leitura, especialmente quando suscita mais perguntas e ambiguidades e estica, ao máximo, a tensão entre o real e o ficcional.

Lísias demonstra ter conhecimento desse modo de funcionamento, reconhecendo que, no momento de produção, já há perda e que a interpretação produz outros sentidos em novos contextos. Sabendo da impossibilidade de controlar e "atuando como honesto", algum tipo de interferência acontece. Em uma de suas entrevistas, ao referir-se a $O$ céu dos suicidas e Divórcio, afirma que, apesar de suas histórias partirem de "experiências pessoais e traumáticas", "isso não significa que o livro [seja] de não-ficção". E completa:

A leitura que alguns grupos da imprensa fizeram do meu livro Divórcio confirma a crítica que o livro faz a eles. O que eu não esperava era que as pessoas fossem cair como patos nas minhas esparrelas. Ingenuidade minha? Talvez... No romance $O$ Céu dos Suicidas, Ricardo Lísias foi campeão Pan-americano de xadrez aos 13 anos. Eu nunca fui campeão de nada, sou um jogador canhestro [...] (LÍSIAS, 2014b).

Ao armar, deliberadamente, as "esparrelas" no limiar da realidade e ficção, Lísias, sem nenhuma ingenuidade, já direciona algum tipo de leitura e, ainda que haja um deslocamento dessa expectativa, consciente dessa possibilidade, a "esparrela" seguinte é calculada a partir de alguma precipitação do leitor. No texto "Sobre a arte e o amor" (LÍSIAS, 2011) que circulou antes da publicação do livro Divórcio, temos uma carta enviada ao "Senhor Arnaldo Vuolo" como resposta à "Notificação extrajudicial subscrita pelo senhor em nome da minha ex-mulher" (LíSIAS, 2011, p. 1), conforme lemos no cabeçalho. Anexas à carta estão uma procuração assinada por Ana Paula Sousa, nome da ex-mulher, além da própria 
notificação endereçada a Lísias pela Vuolo Advogados Associados. O material, portanto, facilmente conduz o leitor a "cair na armadilha", tomando como verdadeiros os elementos com os quais o autor brinca de fazer ficção, mas um tipo de "ficção" que se ancora de maneira recorrente em referências "reais".

Lísias, portanto, demonstra estar atento a todo esse jogo, sabendo "atuar como honesto" e aventurando-se em uma série de lances intencionais, embora não tenha certeza sobre suas consequências. Existe uma disposição para rastrear as apropriações e especulações críticas que são geradas a partir de sua literatura para assim tirar proveito da precipitação dos leitores quando caem na armadilha de que, nos livros mencionados na entrevista, tudo está fundamentado na verdade. Esperando pelo erro, autor atua erformativamente, repetindo e deslocando sua literatura para outros contextos, mas arrastando sua "presença" e emulando uma intencionalidade que está menos conectada à credibilidade e ao esclarecimento, do que ao embaralhamento das possibilidades de interpretação. Assim, "a produção de efeitos", palavras de Derrida, também ocorre à luz do "querer dizer" do autor, se não como instância luminosa, como um elemento a mais capaz de arrevesar as leituras.

Arrematando o argumento e aludindo aos questionamentos sobre a iterabilidade e a "intenção deslocada" em Lísias, é possível dizer que a literatura contemporânea coloca-nos diante de circunstâncias que não estavam postas antes e que, nessa discussão, oferece-nos novas questões para pensar o performativo e seu caráter iterável. Lísias repete características de suas obras em outros contextos, mas opera na direção dessa "recriação de contextos", um gesto que reforça a intenção em vez de enfraquecê-la. Logo, arrisca-se e lança mão de estratégias autorais que, conforme a hipótese levantada, contribui para manter sua assinatura ativa. Em Diário da catástrofe brasileira, como isso se dá?

\section{o não literário da literatura}

Conforme venho argumentando, Lísias escreve e publica o "experimento" Diário da catástrofe brasileira conduzindo a articulação entre vida e obra para outro lugar. Ocorre o deslocamento característico do performativo e, ao mesmo tempo, um empenho do autor em promover esse deslocamento, utilizando sua voz e o recurso tecnológico de outras maneiras até então não testadas por ele, fazendo 
escolhas que indicam um modo de se reinventar para o campo literário e suscitando inquietações quanto à forma do Diário: sai da ficção e, por isso, a princípio, não é literatura? É mesmo um diário? Um libelo político? Uma reflexão que simula um ensaio? Ao especular os possíveis motivos pelos quais o ebook foi pouco vendido (ponto que retomarei adiante), Lísias indaga, no primeiro volume, se estamos diante de um ensaio:

A razão [da baixa vendagem] não é o suporte ebook: há alguns que circulam muito. Um dos leitores me disse que a forma ensaio vende menos. Por sua vez, vejo alguns que estão sendo muito lidos. Não se trata do estranhamento que pode causar um ensaio sendo escrito por alguém reconhecido como um ficcionista? Por algum motivo que sempre me impressionou, no Brasil (ao contrário de outras tradições contemporâneas) isso é raro. O diário da catástrofe brasileira é mesmo um ensaio? (LísIAS, 2019a, n.p., grifo meu).

A última pergunta acaba sendo respondida no segundo volume, $A$ pulsão de morte no poder, quando o autor diz: "Não concordo que esse diário seja um ensaio. Evidentemente, não por conta de qualquer reserva ao gênero. Não acredito em gêneros. De qualquer forma, muitos ensaios tout court circulam bastante, sobretudo quando discutem a realidade política brasileira" (LÍSIAS, 2019b, n.p.). Já no Diário da catástrofe brasileira: o corpo de Lula, o autor afirma: "Esse quarto volume se parece mais tradicionalmente com um ensaio. É o mais adequado para lidar com a questão que discuto" (LíSIAS, 2019c, n.p.). Suas falas, então, vacilam na definição do que é o "experimento".

Ainda que seus posicionamentos neguem ou afirmem o caráter ensaístico do texto e não sejam garantias para validar o que ele pode ser, de fato - e parece-me que Lísias quer, com os ebooks, emular a "inespecificidade" da forma de muitos textos do contemporâneo - cumpre notar que alguns aspectos relativizam a incidência do literário no Diário, como a referência ao processo de escrita e à própria forma do material. Recorrentemente, desde a primeira versão do primeiro volume, o procedimento de escrita e seu inacabamento são descritos, ao passo que são analisados, "em tempo real", os acontecimentos em torno do governo brasileiro:

Vou deixar esse diário de fora da minha programação normal de trabalho. Assim, só volto aqui nos momentos imediatamente anteriores à hora de me deitar. 
Escreverei quatro páginas por dia. Tenho ainda oito linhas. Sete com essa. É um caderno brochura, escolar e com um desenho infantil na capa [...] (LÍSIAS, 2018a, n.p.).

Estou escrevendo esta apresentação enquanto reviso pela última vez o volume III dos Diários da catástrofe brasileira. Em primeiro lugar, admito a ingenuidade de certas passagens. Vou mantê-las inclusive para mostrar como o neofascismo trabalha (LÍSIAS, 2019d, n.p.).

O autor também chama a atenção para algumas características de seu texto, como a opção por não usar conjunções adversativas e por não citar o nome do atual presidente: "[...] Se você achar um 'mas', além desse único, foi porque errei. Com isso, pretendo ser direto e não colocar panos quentes em coisa alguma" (LísIAS, 2019a, n.p.).

Esclareço que, se não houver erro da minha parte, não usarei conjunções adversativas. Do mesmo jeito, inclusive para me preservar, o nome do atual presidente da república não será escrito nenhuma vez. Quando não houver forma de suprimir, vou substituí-lo por [] (LíSIAS, 2019b, n.p.).

Nessas referências ao material, várias vezes é salientado que não se trata de um livro, afinal de contas, para o autor,

um ebook não é um livro. [...] o ebook pode ser diferente do livro impresso. É possivel argumentar que edições sucessivas produziram o mesmo efeito. A experiência de leitura aqui é outra: para ter a edição subsequente, o leitor perde a anterior. Como se viu, não dá nem pra comprar a nova se a outra estiver no dispositivo. Há ainda diversas consequências, que prefiro tratar na prática (LÍSIAS, 2019a, n.p.).

Consoante sua vontade de atualizar o material, Lísias diz em nota na segunda versão que se isenta da responsabilidade autoral do ebook que foi substituído, afirmando que

a primeira [versão] foi publicada há um mês. Já não me sinto seu autor. Se você está lendo essa nota, continua no âmbito da criação. Quem não atualizar o Diário 
está fora do meu trabalho e portanto torna-se o único responsável pela versão anterior. Ela já não me diz respeito (LíSIAS, 2018b, n.p.).

Essa mise-en-scène em relação à autoria, contudo, não é retomada nas versões seguintes. Também na segunda versão, o autor destacou os trechos que sofreram modificações, o que não se manteve na atualização seguinte: "Na versão anterior, deixei as atualizações em azul. Meu receio era o de que muitos leitores só lessem esses novos trechos. Como o objetivo político aqui é evidente e a repetição, decisiva, não vou fazer isso de novo" (LÍSIAS, 2019a).

A voz autoral, então, sinaliza a necessidade de atualização para o acesso à obra "em andamento" que tensiona "o lembrar" e "o esquecer", pois, de um lado, capta o caos político da atualidade para registrá-lo e reprisá-lo e, de outro, apaga o que já escreveu, apoiando-se na volatilidade que o suporte tecnológico pode proporcionar. E aqui é inevitável mencionar a escolha do "diário" para a composição do título, já que o gênero, tradicionalmente, arquiva a memória, mas é explorado nesse caso - pelo menos à primeira vista - a partir da efemeridade. À primeira vista porque, a despeito do jogo em torno do apagamento e da isenção da responsabilidade autoral das versões substituídas, Lísias registra, revisa, relembra e, assim, vai criando uma espécie arquivo.

O tensionamento entre o registro e o apagamento, entre a emulação do gênero e sua rasura, entre o escrever e o publicar ou, em suma, entre a repetição e a diferença, vai confirmando o caráter performativo do Diário e da sua relação com os textos precedentes, uma vez que, a seu modo, repete o procedimento que inscreve o trabalho de Lísias no limiar entre vida e obra, à medida que rompe com essa produção anterior porque aposta em uma saída da ficção. Esse gesto, no entanto, configura mesmo uma saída? Se sim, - e retomando a questão que trouxe mais atrás - uma saída em nome de quê? Da necessidade do registro documental porque o que estamos vivendo parece ser tão fictício que a literatura não dá conta? Ou não está mais claro hoje o que é o literário da literatura e Lísias tem tirado partido de uma suposta transformação em curso?

Acredito que todo esse engajamento na direção de um procedimento performativo, o "querer dizer" do autor, opera para manter seu nome circulando no campo literário. Não podemos negar, é claro, que Lísías mostra-se entusiasmado com questões políticas e sociais desde o início de sua carreira e, antes mesmo do período eleitoral, já se posicionava contra o então presidente e a tudo aquilo que 
estivesse relacionado a ele. Não obstante, esse interesse pessoal e genuíno é potencializado em prol de estratégias que se somam para dar visibilidade ao autor e manter ativa sua assinatura.

De maneira mais fácil e rápida, Lísias encarrega-se de todos os papéis relacionados à produção e circulação dos ebooks: escreve, revisa, formata, autopublica-se, divulga, monitora as vendas, divulga novamente e faz comentários sobre a recepção do texto. Ao final da segunda versão do primeiro volume, foram apresentados, numa espécie de anexo, alguns comentários negativamente críticos dirigidos ao "experimento", o que indica, em primeiro lugar, a já mencionada disposição do autor em rastrear a recepção e, em segundo, uma atitude defensiva, a qual, posteriormente, é reconhecida por ele, quando decide retirar o anexo na versão posterior: "As atualizações dessa vez foram ainda maiores. Cortei o trecho sobre as críticas, pois ele me pareceu agora muito defensivo" (LÍSIAS, 2019a, n.p.).

Atentando para a recepção, ele também compartilha as análises positivas e afere as vendas do Diário, já que tem acesso ao número de downloads e as avaliações deixadas pelos clientes da Amazon no próprio site, ou seja, a rápida aferição é viabilizada pelo fato de o "experimento" circular em uma única plataforma on-line. Conforme afirmou em uma das atualizações do primeiro ebook (e aqui retorno à questão das vendas): "o Diário da catástrofe brasileira vendeu menos que meus outros livros (impressos) no mesmo período. Acho que a metade, desconsiderando o enorme sucesso de arranque que o romance Divórcio teve" (LÍSIAS, 2019a, n.p.). No segundo volume, reiterou que

o fato do Diário da catástrofe brasileira estar circulando bem menos que as minhas outras criações intensificou a sensação depressiva de fracasso. A essa altura, em número de pessoas engajadas no experimento, eu esperava cinquenta por cento a mais, baseando-me nos meus outros projetos, inclusive o Delegado Tobias, que também foi uma publicação eletrônica. $O$ fato de se tratar de um ebook não me parece, a princípio, um problema: alguns têm enorme quantidade de engajamento (LÍSIAS, 2019b, n.p.).

Por outro lado, quando alguma das versões do Diário esteve entre os mais vendidos da Amazon, o autor divulgou em suas redes sociais, fomentando sua já recorrente inclinação para anunciar o próprio trabalho. Somam-se a isso as divulgações que fez dos convites recebidos e das participações em debates para falar sobre a "análise estética da nova extrema direita", tema que ganhou espaço 
no terceiro volume do Diário ${ }^{12}$. Diante desses movimentos, é interessanteobservar que, embora os ebooks partam de um investimento que, a princípio, sai da literatura, o autor não deixa de transitar no campo literário. Desse modo, estou pontuando que Lísias retira o estatuto ficcional de seu trabalho, porém ainda segue operando no âmbito da literatura, uma vez que continua repetindo seus já conhecidos procedimentos autorais, como o rastreamento da recepção, a divulgação do trabalho e as falas em eventos acadêmicos e literários. Duas situações corroboram essa afirmação.

A primeira delas refere-se a uma publicação na página do Instagram do autor. Em 24 de abril de 2019, por ocasião do lançamento do edital do Prêmio Rio de Literatura, Lísias postou uma "Carta aberta aos curadores do Prêmio Rio de Literatura", na qual critica o critério do concurso que não permite a inscrição de obras oriundas de plataformas de autopublicação, como o caso de Diário da catástrofe brasileira. Vejamos um trecho da postagem:

Amigos curadoras e curadores: antes de tudo peço desculpas por me dirigir dessa forma, mas não achei em lugar nenhum quem seriam vocês. O Google, ao menos para mim, falhou. Como, porém, é um mundo diminuto, tenho certeza de que em quinze minutos já estaremos em contato. [...] me surpreendi com a

12 Lísias faz a análise partindo do pressuposto de que a nova extrema direita baseia sua propaganda na massiva profusão de imagens, facilitada pelo advento das redes sociais e não restrita apenas ao período de campanha eleitoral. Fazendo irônica alusão ao universo das artes plásticas, adverte: "É uma gigantesca galeria cujas obras podem ser vistas a qualquer hora, em qualquer parte do planeta, por qualquer pessoa conectada à internet. [...]. Se não estamos falando da melhor arte realizada atualmente, tampouco podemos descartar esse acervo como mera e casual iconografia. É um material que está moldando um momento histórico, produzindo significados e revelando anseios [...]. Em todos os acervos é possível vislumbrar a intenção política de seus criadores, curadores e divulgadores, pois cada um deles contém conteúdo e padrão estético bem definidos, além de serem dirigidos a públicos e faixas etárias diferentes. As imagens podem ser classificadas como populares, escatológicas e repugnantes. Tudo funciona como um museu, com suas diversas alas e atividades [...]. Embora muitos trípticos apareçam na propaganda da extrema direita, formalmente falando a maior parte do material é formada por dípticos ou por apenas uma imagem. Um subtipo muito comum são as obras com duas fotografias lado a lado, sempre em choque" (LíSIAS, 2019d, n.p.). Assim como apresenta imagens que circularam em sites abertos antes e após a campanha eleitoral dos atuais presidentes do Brasil e dos Estados Unidos, Lísias também traz exemplos de propagandas produzidas por outros grupos que se manifestaram, principalmente, no período da campanha e que visavam combater ou ressaltar as contradições no discurso do candidato eleito, o que, para o autor do Diário, foi inócuo, considerando que "pesquisas recentes mostram que os grupos que aderem ao discurso da extrema direita não costumam sequer ter contato com outras ideias" (LíSIAS, 2019d, n.p.). 
notícia de que os senhores não permitem a inscrição de obras que saíram em plataformas de autopublicação. Infelizmente, a data em que publiquei o "Diário da catástrofe brasileira I - transição" na Amazon não permite que eu o inscreva esse ano. Mas eu pretendo fazer isso o ano que vem - se estivermos aqui até lá, é claro. Acho que a definição de arte (não sei bem se ainda faz sentido falar só em literatura, mas isso não vem ao caso agora) deve sempre caminhar no sentido da ampliação, e não no da restrição. A autopublicação não tem evidentemente nada a ver com a importância de uma editora, o que ninguém duvida. É na verdade uma opção formal. Tenho ainda uma segunda questão: os senhores afirmam no edital queaceitam a inscrição de ebooks, mas que devem ser entregues 12 cópias impressas do ebook inscrito. Se me permitem a observação, isso não tem sentido. Se dá para imprimir, não é um ebook, mas sim um livro impresso, por evidente. Se querem uma versão impressa, na prática os senhores não permitem a inscrição de ebooks... Dessa forma, peço que os senhores considerem meus argumentos, caso venham a lançar uma nova edição do importante prêmio no ano que vem. [...]. Muito obrigado, um abraço, Ricardo Lísias. 24 de abril de 2019. ${ }^{13}$

Por "opção formal", ele não apenas escolhe o formato ebook e o Kindle Direct Publishing, como não define ao certo o que é o Diário da catástrofe brasileira (apenas no quarto volume aproxima o "experimento" de um gênero, que é o ensaio). Apesar de não precisar se é ou não literatura, demonstra interesse em inscrevê-lo em um conhecido prêmio literário do estado do Rio de Janeiro, que, na edição de 2019, apresentou as categorias "prosa de ficção", "ensaio", "poesia" e "novo autor fluminense". Vejo essas escolhas, então, menos como uma saída, propriamente, da literatura, do que um entendimento do autor de que a produção literária atual não está mais tão delimitada como já estivera, o que é endossado pela sua declaração sobre a ampliação da arte. Soma-se a isso seu interesse em circular no campo literário para manter a assinatura ativa e, assim, adequar-se, por exemplo, aos critérios de um regulamento cujas categorias são bem delimitadas (por que ainda não dão conta da expansão artística que o contemporâneo suscita?). Não sendo possível adequar-se a tais critérios, para não violar sua "opção formal", argumenta e solicita uma reconsideração.

Mas talvez pela necessidade de "adequar-se" para preservar sua assinatura (e aqui me dirijo à segunda situação a qual me referi), Lísias declarou no quarto volume do Diário, O corpo de Lula, que, em 2020, publicará o material em formato

13 Disponível em: <https://bit.ly/2mr5ARv>. Acesso em 25 abr. 2019. 
livro: "O Diário da catástrofe brasileira será impresso e publicado pela editora Record nos primeiros meses de 2020. Não será a mesma versão dos ebooks. Vou selecionar o que não deve desaparecer. Sou um dos tantos que cometeram erros de análise" (LíSIAS, 2019c, n.p.). A mudança de planos parece responder à própria (in)definição do que é o Diário da catástrofe brasileira: um "experimento". Fazendo jus ao rótulo, o autor experimenta, testa, observa: utiliza um novo formato, apostando na ferramenta da autopublicação digital e publicando versões atualizáveis, e, sendo uma experimentação, seus resultados não estão previstos de antemão. Desde a publicação do primeiro volume, Lísias vem aferindo cada uma de suas investidas. Planejou a atualização dos ebooks, lançou mão e depois se desocupou do discurso em torno da isenção da responsabilidade autoral - talvez porque seu efeito não foi o esperado - e voltou atrás na decisão de deixar em destaque os trechos modificados e as críticas dos leitores, para citar alguns exemplos.

Observando a repercussão de cada escolha relacionada ao Diário, não é por acaso que, quase um ano depois do lançamento do primeiro ebook, opte pela publicação impressa por uma grande editora, mesmo depois de enfatizar, no início de tudo, que as versões estariam disponíveis apenas em formato digital e que, ao final do "governo da catástrofe", apagaria o material da plataforma. Apesar de algumas das versões aparecerem na lista do mais vendidos do site, Lísias referiu-se no próprio texto, por mais de uma vez, ao não expressivo número de downloads e às vendas inferiores em relação a outros de seus livros, sem contar as dificuldades para atualização, no início, e o interesse do autor em pleitear o Prêmio Rio de Literatura, cujos critérios não possibilitam a inscrição do "experimento" na forma como se encontra atualmente.

Vale ressaltar, contudo, que o autor não sinalizou o abandono da publicação virtual. Resta-nos saber se vai conduzi-la até o final de 2022 da maneira inicialmente proposta, com as atualizações periódicas. Seja como for, ebook ou livro, é possivel dizer, em última instância, que, com o Diário, Lísias está lidando com as dimensões performativas do escrever e do publicar. Ele repete um procedimento de escritor ("escrevo, logo, publico") - seu procedimento de escritor ("escrevo, publico, divulgo, monitoro a crítica, altero as estratégias") - ao mesmo tempo em que pressupõe um deslocamento ("não é ficção", "não é livro"). Esse deslocamento "arrasta" a "presença" do autor, que, com seus lances intencionais, não controla as apropriações de seu trabalho, mas atua sobre tais apropriações. Consciente disso e atento para a repercussão, calcula, antecipadamente, a estratégia seguinte, buscando sustentar 
seu nome no campo literário, uma atitude performativa que atravessa o Diário e a sua relação com os seus outros trabalhos.

\section{referências}

AGUILAR, Gonzalo; CÁMARA, Mario. A máquina performática: a literatura no campo experimental. Tradução de Gênese Andrade. Rio de Janeiro: Rocco, 2017.

AUSTIN, John. Performativo-Constativo. Tradução de Paulo Ottoni. In: OTTONI, Paulo. Visão performativa da linguagem. Campinas: Editora da Unicamp, 1998.

CUNHA, Eduardo (pseudônimo). Diário da cadeia: com trechos da obra inédita Impeachment. Rio de Janeiro: Record, 2017.

DERRIDA, Jacques. Assinatura Acontecimento Contexto. In: DERRIDA, Jacques. Limited Inc. Tradução Constança Marcondes Cesar. Campinas: Papirus, 1991. p. 11-37.

FISH, Stanley. With the Compliments of the Author: Reflections on Austin and Derrida. Critical Inquiry Tthe University Of Chicago Press), Chicago, v. 8, n. 4, p.693-721, 1982. Disponível em: <https://bit.ly/32wMU1t>. Acesso em: 7 out. 2018.

GARRAMUÑO, Florencia. Frutos Estranhos: Sobre a inespecificidade na estética contemporânea. Rio de Janeiro: Rocco Digital, 2014. EPUB. Não paginado.

KLINGER, Diana. Escritas de si, escritas do outro: o retorno do autor e a virada etnográfica. 3. ed. Rio de Janeiro: 7Letras, 2012.

LÍSIAS, Ricardo. Diário da catástrofe brasileira I - transição. Kindle Direct Publishing, Amazon: 2018a. eBook Kindle. Não paginado.

LÍSIAS, Ricardo. Diário da catástrofe brasileira l - transição (2 ${ }^{a}$ versão). Kindle Direct Publishing, Amazon: 2018b. eBook Kindle. Não paginado.

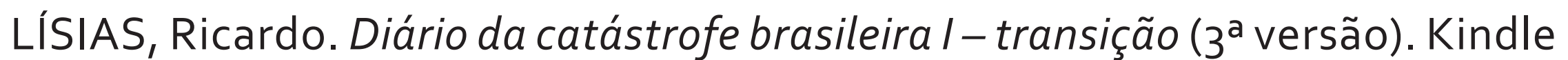
Direct Publishing, Amazon: 2019a. eBook Kindle. Não paginado. 
LÍSIAS, Ricardo. Diário da catástrofe brasileira ll - a pulsão de morte no poder. Kindle Direct Publishing, Amazon: 2019b. eBook Kindle. Não paginado.

LÍSIAS, Ricardo. Diário da catástrofe brasileira III-o nazifascismo se consolida. Kindle Direct Publishing, Amazon: 2019d. eBook Kindle. Não paginado.

LÍSIAS, Ricardo. Diário da catástrofe brasileira IV - o corpo de Lula. Kindle Direct Publishing, Amazon: 2019c. eBook Kindle. Não paginado.

LÍSIAS, Ricardo. Divórcio. Rio de Janeiro: Alfaguara, 2013.

LíSIAS, Ricardo. Delegado Tobias. São Paulo: E-galáxia, 2014a. EPUB. Não paginado.

LíSIAS, Ricardo. "Há dificuldade de aceitação, no Brasil, do aspecto ideológico da arte". 2014b. Entrevista concedida a Éder Silveira e Milton Ribeiro. Disponivel em: <https://bit.ly/2PBpZz8>. Acesso em: 14 set. 2019.

LíSIAS, Ricardo. O Céu dos suicidas. Rio de Janeiro: Alfaguara, 2012.

LíSIAS, Ricardo. O livro dos mandarins. Rio de Janeiro: Alfaguara, 2009.

LíSIAS, Ricardo. Sem título: uma performance contra Sérgio Moro. Rio de Janeiro: Oficina Raquel, 2018c.

LISIAS, Ricardo. Sobre a arte e o amor. [S. I.]. 2011. Não publicado.

MARCONDES, Danilo. Prefácio. In: OTTONI, Paulo. Visão performativa da linguagem. Campinas: Editora da Unicamp, 1998.

OTTONI, Paulo. Visão performativa da linguagem. Campinas: Editora da Unicamp, 1998.

SILVA, Daniel; VERAS, Viviane. Da teoria dos atos de fala à nova pragmática: os legados de John L. Austin e Kanavillil Rajagopalan. Delta: Documentação e estudos em linguística teórica e aplicada, São Paulo, v. 32, n. 3, p. 5-19, 2016. Disponível em: <https://bit.ly/2rorcOl>. Acesso em: 12 ago. 2019.

Artigo recebido em: 21/01/2020

Aceito em: 17/05/2020 